\title{
KONCEPCJA OSIEDLA REKREACYJNEGO? PRZYKŁAD OSIEDLA LYKKE W WARSZAWIE
}

\author{
THE IDEA OF RECREATIONAL HOUSING ESTATE? \\ A CASE STUDY OF LYKKE HOUSING ESTATE IN WARSAW
}

DOI: $10.25167 / \mathrm{sm} 2017.025 .09$ s. $149-161$

\begin{abstract}
ABSTRAKT: Osiedle Lykke to pierwsze osiedle w Warszawie, którego główną ideą jest wspieranie i rozwijanie aktywności fizycznej mieszkańców. Cel ten ma zostać osiągnięty poprzez odpowiednie zagospodarowanie przestrzeni osiedla oraz jego lokalizację w bezpośrednim sąsiedztwie komercyjnej i niekomercyjnej przestrzeni rekreacyjnej (w tym w sąsiedztwie terenów zieleni). Przeprowadzone wśród mieszkańców osiedla badanie wykazało, że koncepcja takiego zagospodarowania przestrzeni jest odbierana pozytywnie, poszczególne elementy osiedla są dobrze oceniane i wykorzystywane przez mieszkańców, a zaprojektowana w ten sposób przestrzeń ma faktycznie duży potencjał w kształtowaniu aktywnego stylu życia mieszkańców.
\end{abstract}

SŁOWA KLUCZOWE: osiedle mieszkaniowe, rekreacja, aktywność fizyczna

ABSTRACT: Lykke housing estate is the first housing estate in Warsaw, whose main idea is to develop and support physical activity of its inhabitants. In order to achieve this goal, Lykke housing estate was appropriately planned and located in a special neighbourhood of green areas and sports infrastructure. The research carried out among the inhabitants of $L y k k e$ showed that the idea of recreational space organisation is perceived in a positive light and is readily made use of by inhabitants, the public space of Lykke presenting crucial potential for the development of an active lifestyle.

KEY WORDS: housing estate, recreation, physical activity

\section{Wprowadzenie}

Jedną z najważniejszych funkcji miast jest funkcja mieszkaniowa, a jedną z form organizacji tej funkcji są osiedla mieszkaniowe. Człowiek oprócz potrzeb podstawowych (potrzeby biologiczne, potrzeba zamieszkania) posiada również potrzeby ruchu, kształtowania własnej osobowości i dbania o siebie. Jedną z możliwości realizacji tych potrzeb jest odpowiednie zagospodarowanie miast i tworzenie przestrzeni rekrea-

\footnotetext{
* Uniwersytet Warszawski, Wydział Geografii i Studiów Regionalnych, Zakład Geografii Miast i Organizacji Przestrzennej, ul. Krakowskie Przedmieście 30, 00-927 Warszawa, e-mail: mfuhrmann@uw.edu.pl
} 
cyjnych. Te ostatnie mogą powstawać również w granicach osiedli mieszkaniowych. W przeważającej liczbie koncepcji osiedli mieszkaniowych funkcja rekreacyjna jest jedynie jedną z wielu tam realizowanych, obok funkcji usługowej czy edukacyjnej. Prezentowane w artykule osiedle Lykke jest przykładem pierwszego osiedla w Warszawie, którego najważniejszą funkcją (poza mieszkaniem) stały się rekreacja i kształtowanie aktywności fizycznej mieszkańców w różnym wieku. Takie podejście w formowaniu przestrzeni mieszkaniowej może się stać obecnie szczególnie istotne, gdy ruch i aktywność fizyczna stały się elementami stylu życia, a świadomość konieczności dbania o zdrowie z roku na rok rośnie.

\section{Koncepcje osiedli mieszkaniowych w XX w.}

Po drugiej wojnie światowej, w okresie wzmożonego zapotrzebowania na nowe lokale mieszkaniowe i odbudowę miast, rozwój urbanistyczny następował według kilku modeli: modernistycznego, socjalistycznego, postmodernistycznego i współczesnego (Komar 2012).

Model modernistyczny zakładał rozłączenie funkcji mieszkaniowej od pozostałych funkcji miasta (przemysłowej, produkcyjnej, usługowej). Budynki sytuowane były zgodnie ze stronami świata, co zapewniało odpowiednie nasłonecznienie pomieszczeń i przewietrzanie kompleksu mieszkaniowego. Z tego okresu pochodzą koncepcje jednostki sąsiedzkiej Clarence’a A. Perry'ego i osiedla społecznego Heleny i Szymona Syrkusów oraz Barbary Brukalskiej (Syrkus 1976, Brukalska 1948).

Model socjalistyczny również zakładał odseparowanie funkcji mieszkaniowej od przemysłowej, ale na większą skalę. Prowadziło to do powstawania miast z przewagą funkcji mieszkaniowej. Istotnymi cechami zabudowy mieszkaniowej były monotonia i ujednolicenie lokali mieszkalnych pod względem powierzchni i funkcjonalności. Postmodernistyczne podejście do zabudowy mieszkaniowej oznaczało powrót do klasycznego ujęcia kompozycji urbanistycznej i przestrzeni publicznej. Model ten był przeciwieństwem monofunkcyjności okresu modernizmu. Podejście współczesne zaczęto stosować w latach 70. XX w., a zasady zabudowy formowane były ciągle do początku XXI w. (Nowa Karta Ateńska 2003). Zwrócono uwagę na skalę budowanych osiedli mieszkaniowych, ich spójność i humanistyczny charakter i równoważenie (Komar 2012).

\section{Zagospodarowanie osiedla mieszkaniowego}

Sposób zagospodarowania przestrzennego osiedla mieszkaniowego bezpośrednio kształtuje funkcje osiedla. Do elementów zagospodarowania osiedla można zaliczyć:

- teren mieszkaniowy obejmujący budynki mieszkalne, przestrzeń między budynkami, place zabaw, parkingi, 
- urządzenia usługowe (sklepy, budynki edukacyjne),

- zieleń osiedlową,

- tereny komunikacyjne (Ostrowski 1971).

Na zagospodarowanie przestrzenne osiedla mieszkaniowego można spojrzeć bardziej szczegółowo (Korzeniewski 1989). Osiedle obejmuje wtedy:

- budynki mieszkalne i tereny przydomowe,

- zabudowę handlową i usługową (opieka zdrowotna, handel, gastronomia, administracja i in.),

- zabudowę o funkcji edukacyjnej i oświatowej,

- tereny otwarte wraz z zielenią osiedlową o różnych funkcjach i tereny rekreacyjne,

- tereny komunikacyjne (obsługa ruchu pieszego i kołowego).

Biorąc pod uwagę poszczególne elementy zagospodarowania przestrzeni osiedla, należy stwierdzić, że poza funkcją mieszkaniową może ono pełnić także inne funkcje, takie jak:

- wypoczynkowa i rekreacyjna,

- edukacyjna,

- zaspokojenia potrzeb związanych z nabywaniem usług,

- zaspokojenia potrzeb związanych z utrzymaniem zdrowia,

- społeczna (integracja mieszkańców, identyfikacja z miejscem zamieszkania, tabela 1).

Tabela 1

Relacje między funkcjami a zagospodarowaniem osiedla mieszkaniowego

\begin{tabular}{|l|l|}
\hline \multicolumn{1}{|c|}{ Funkcja osiedla } & \multicolumn{1}{c|}{ Zagospodarowanie osiedla } \\
\hline $\begin{array}{l}\text { Wypoczynkowa i rekre- } \\
\text { acyjna }\end{array}$ & $\begin{array}{l}\text { piaskownice, huśtawki, sprzęty zabawowe, górki saneczkowe, boiska do } \\
\text { gier zespołowych, stanowiska do gier, siłownia plenerowa, zieleń osiedlowa }\end{array}$ \\
\hline Edukacyjna & żłobki, przedszkola, szkoły, domy kultury, zieleń osiedlowa \\
\hline Usługowa & sklepy, punkty gastronomiczne i in. \\
\hline Zdrowotna & przychodnie, ośrodki zdrowia, zieleń osiedlowa \\
\hline Społeczna & $\begin{array}{l}\text { tworzenie przestrzeni półpublicznych, elementy małej architektury, miej- } \\
\text { sca spotkań, urządzenia rekreacyjne, przestrzenie wspólne }\end{array}$ \\
\hline
\end{tabular}

Źródło: Opracowanie własne.

Funkcja wypoczynkowa i rekreacyjna osiedla mieszkaniowego może być realizowana przez różne elementy zagospodarowania i być skierowana do odbiorców w różnym wieku (Piątkowska, Scholtz, Wirszyłł 1976). Janusz Szkiłądź (1979) wyróżnia:

- tereny rekreacji dzieci (piaskownice, huśtawki, szałasy, altany, palisady, sprzęty zabawowe, górki saneczkowe),

- tereny rekreacji dorosłych (fontanny i baseny ozdobne, cieki wodne, schody, pergole i trejaże, murki ozdobne i oporowe, miejsca do siedzenia i stoły, rzeźby i amfiteatry).

Na szczególną uwagę zasługują tereny zieleni osiedlowej, które mogą jednocześnie pełnić kilka funkcji w osiedlu mieszkaniowym: 
- biologiczno-zdrowotną (produkcja tlenu, pochłanianie dwutlenku węgla, zatrzymywanie zanieczyszczeń, tworzenie mikroklimatu osiedla, oddziaływanie na samopoczucie człowieka),

- wypoczynkową, rekreacyjną,

- izolacyjną (tłumienie hałasu),

- przestrzenno-plastyczną, estetyczną,

- dydaktyczno-wychowawczą (kontakt z przyrodą) (Lipińska 1977).

Jak wskazują Jan M. Chmielewski i Małgorzata Mirecka (2001), funkcje przestrzeni osiedlowej i ich zakres uzależnione są od układu zabudowy osiedla. Usytuowanie i wielkość bloków mieszkalnych warunkują powstawanie przestrzeni wewnętrznej. Przestrzeń ta daje inne możliwości użytkowania osiedla w przypadku zabudowy blokowej, gniazdowej, meandrowej czy liniowej i grzebieniowej (rysunek 1). Dobrze zaprojektowana przestrzeń osiedla mieszkaniowego tworzy jego tożsamość i sprzyja utrwalaniu więzi mieszkańców z miejscem zamieszkania, jak również kreuje pozytywny wizerunek miejsca i może się przekładać na formowanie i umacnianie więzi i relacji społecznych (Jak przetworzyć miejsce...).
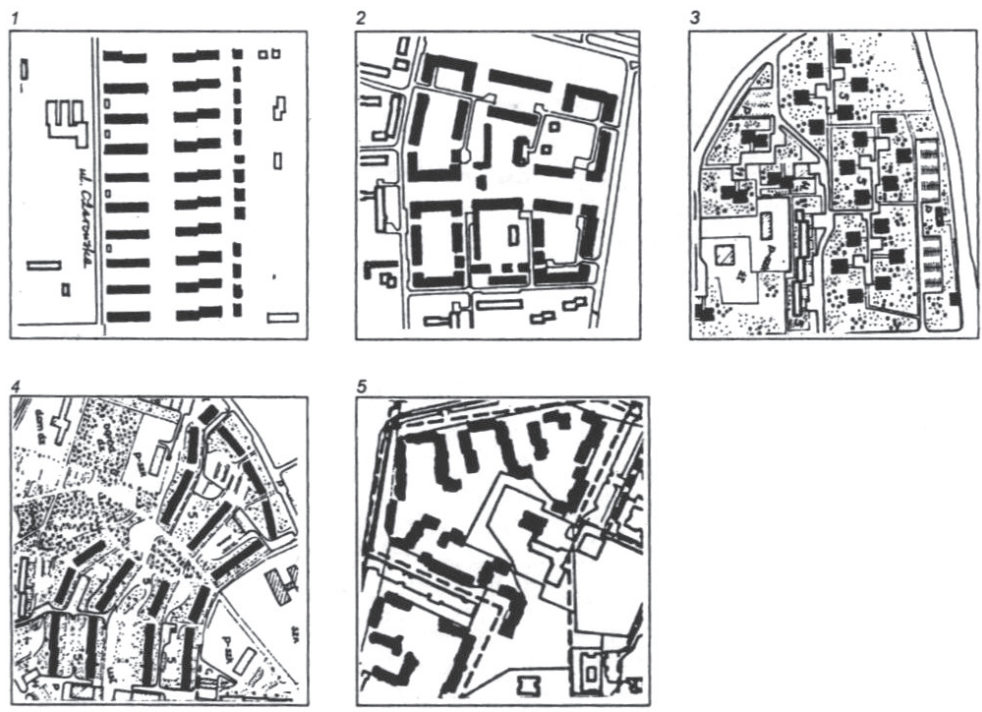

Rys. 1. Układy zabudowy osiedla mieszkaniowego: 1 - grzebieniowy, 2 - blokowy, 3 - gniazdowy, 4-liniowy, 5 - meandrowy

Źródło: Chmielewski, Mirecka 2001.

\section{Metodologia}

Badaniu poddano osiedle Lykke w Warszawie i jego mieszkańców. Jest to obecnie jedyne osiedle w Warszawie i w Polsce zbudowane według nowego podejścia, uznającego 
rekreację za nadrzędną funkcję (poza funkcją mieszkaniową) i kierunek w zagospodarowaniu przestrzennym osiedla. Układ zabudowy osiedla nie jest jednoznaczny, bloki mają różną wielkość i kształt, a ich wzajemne usytuowanie pozwoliło na wydzielenie dużej powierzchni wspólnej osiedla i jej korzystne zagospodarowanie (rysunek 2). Badanie kwestionariuszowe zostało przeprowadzone w lipcu 2015 r. Wzięło w nim udział 98 osób (39,2\% wszystkich mieszkańców). Zastosowany kwestionariusz ankiety przygotowany został przez autorkę niniejszego artykułu. Obejmował on 33 pytania właściwe i metryczkę (wiek, płeć, wykształcenie, aktywność zawodowa). Pytania te podzielone były na następujące bloki tematyczne:

a. ocena funkcjonowania administracji osiedla i dewelopera,

b. ocena miejsca zamieszkania,

c. wykorzystanie elementów zagospodarowania przestrzennego,

d. relacje społeczne mieszkańców,

e. aktywność fizyczna mieszkańców.

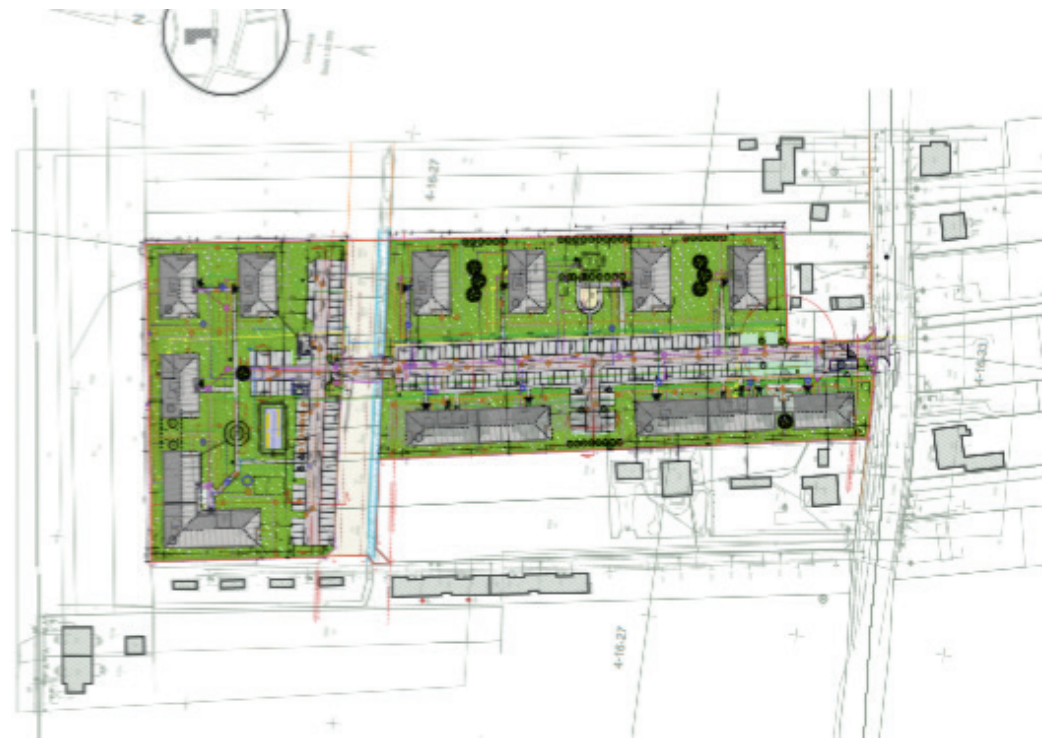

Rys. 2. Schemat osiedla Lykke w Warszawie

Źródło: Unidevelopment S.A.

\section{Osiedle Lykke w Warszawie i jego zagospodarowanie}

Osiedle zlokalizowane jest w warszawskiej dzielnicy Białołęka (Zielona Białołęka) w odległości ok. $15 \mathrm{~km}$ od centrum miasta (rysunek 3). Jego nazwa pochodzi od norweskiego słowa lykke oznaczającego szczęście. Osiedle powstało w 2015 r., a jego budowa trwała 1,5 r. Jest to kompleks mieszkaniowy 9 budynków o całkowitej powierzchni 
działki 17429 m² $^{2}$ (rysunek 1). Lykke oferuje 165 mieszkań w budynkach dwupiętrowych. Powierzchnia mieszkań zawiera się w przedziale od 33 do $80 \mathrm{~m}^{2}$, część lokali posiada dwie kondygnacje (antresola) lub ogród przydomowy. Każdy budynek wyposażony jest w windy i domofony. Osiedle jest typu zamkniętego i strzeżonego. Dostęp do niego jest ograniczony, a bezpieczeństwa mieszkańców pilnuje ochrona. Lykke zostało zlokalizowane w sąsiedztwie szkól, przedszkoli, sklepów, bibliotek.

Do zagospodarowania osiedla zalicza się:

- boisko do koszykówki,

- boisko do piłki nożnej,

- siłownię plenerową

- dwa place zabaw,

- stoliki do gry w szachy i chińczyka,

- miejsca do organizacji pikników,

- wybieg dla psów,

- parking, w tym parking dla gości.

Najważniejszą cechą osiedla Lykke jest sposób zagospodarowania jego przestrzeni otwartej, która pełni przede wszystkim funkcję rekreacyjną. Oferta Lykke skierowana jest do osób aktywnych fizycznie. W tym aspekcie nie bez znaczenia pozostaje otoczenie

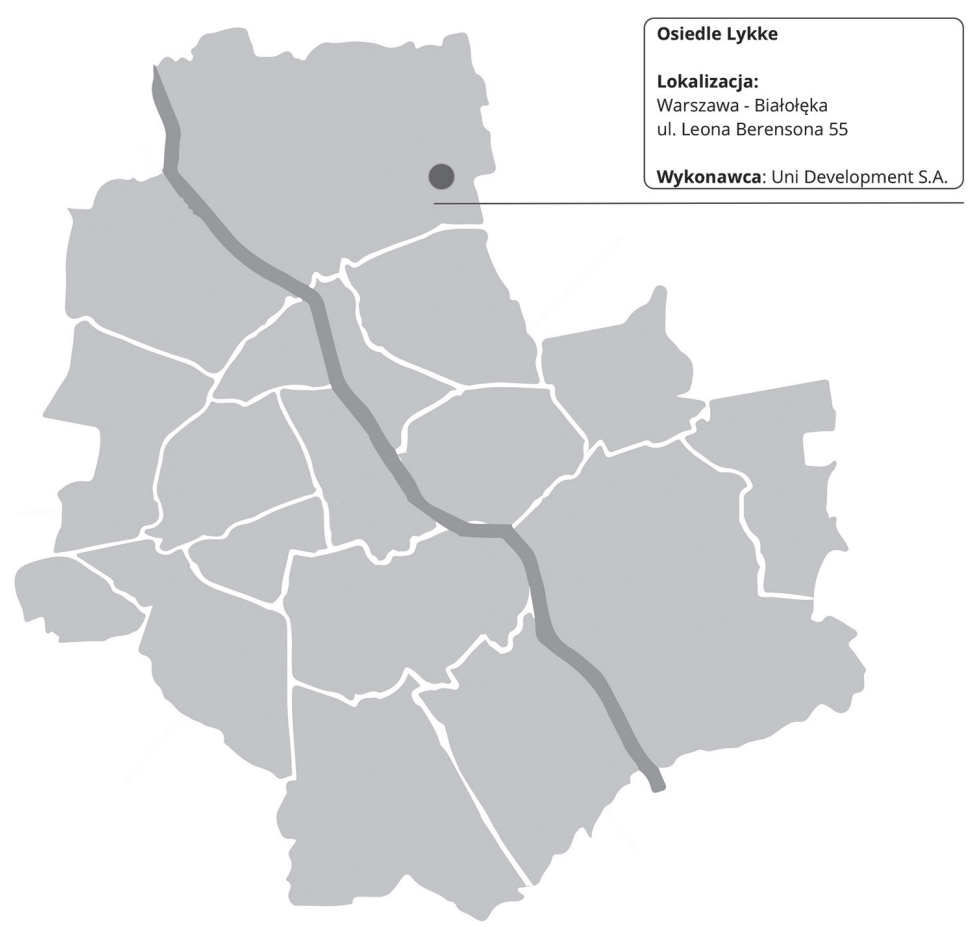

Rys. 3. Lokalizacja osiedla Lykke w Warszawie Źródło: Jak w rysunku 1. 
osiedla. W jego bezpośrednim sąsiedztwie znajdują się tereny zieleni i trasy rowerowe - oferta szczególnie istotna dla aktywności fizycznej: bieganie, rower, nordic walking, spacery. Teren wokół osiedla wyposażony jest również w bezpłatną i odpłatną infrastrukturę rekreacyjną. Zaliczają się do niej: siłownie plenerowe, kluby fitness, kompleksy basenowe oraz stadnina koni. W odległości $15 \mathrm{~km}$ położony jest Zalew Zegrzyński umożliwiający realizację potrzeb w zakresie sportów wodnych.

\section{Kampania reklamowa i promocja osiedla Lykke}

Działania marketingowe związane z powstaniem osiedla obejmowały: komunikację wizualną, reklamę zewnętrzną, marketing bezpośredni, wydarzenia, reklamę prasową oraz reklamę w serwisach społecznościowych. Komunikacja wizualna opierała się przede wszystkim na ulotkach, broszurach informacyjnych oraz stronie WWW (rysunek 4).

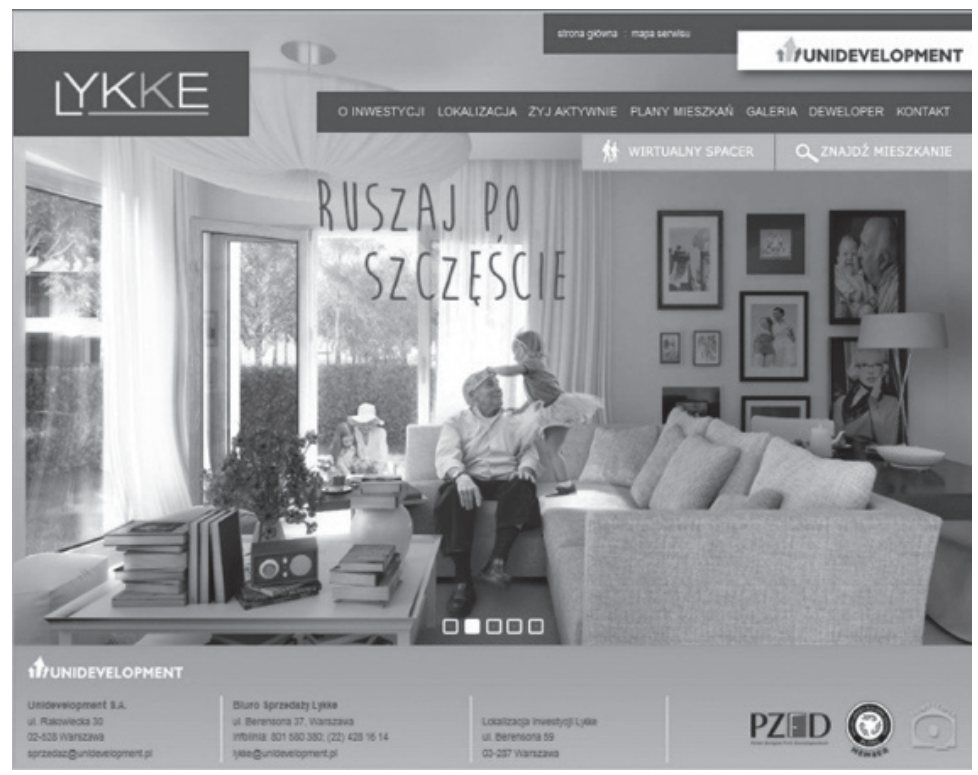

Rys. 4. Projekt strony głównej WWW osiedla Lykke

Źródło: Zasoby Unidevelopment S.A.

Reklama zewnętrzna w przypadku osiedla Lykke obejmowała reklamę wielkoformatową (billboard, backlight, tablice reklamowe i airwall). Miała on na celu podniesienie świadomości istnienia osiedla na warszawskim rynku nieruchomości oraz podkreślenie wyjątkowości oferty i jej cech na tle konkurencji. Informacje o osiedlu Lykke pojawiły się również w komunikacji miejskiej. Przekaz miał postać spotu reklamowego oraz plakatów. 
W ciekawy sposób do promocji osiedla wykorzystano marketing bezpośredni. Unidevelopment S.A. zorganizował „dni aktywności osiedla Lykke”. Dzięki temu przedsięwzięciu można było bezpośrednio zaprezentować ofertę oraz utrwalić jego wizerunek Lykke jako miejsca dla osób aktywnych fizycznie (organizacja zabaw i gier sportowych również z udziałem pracowników pobliskich klubów fitness), a także wywołać pozytywne skojarzenia z osiedlem.

Skorzystano również ze wsparcia reklamy prasowej (w prasie codziennej) oraz reklamy na portalu Facebook. Zastosowanie reklamy w portalu społecznościowym dało możliwość dotarcia z przekazem do dokładnie określonej grupy odbiorców, którzy mogli być zainteresowani zakupem mieszkania na osiedlu Lykke.

\section{Charakterystyka respondentów}

Liczba mieszkańców osiedla w okresie przeprowadzenia badania wynosiła 250 . W badaniu wzięło udział 98 osób, co stanowi 39,2\% wszystkich mieszkańców, a respondenci pochodzili z $60 \%$ mieszkań. Ponad połowę badanych stanowiły kobiety $(56,8 \%)$. Średnia wieku respondentów wyniosła 31 lat. Osoby w wieku powyżej 40 lat stanowiły jedynie $6,3 \%$ badanych, a tylko cztery osoby były w wieku powyżej 60 lat. Ponad $80 \%$ badanych przeprowadziło się na osiedle Lykke z innych osiedli w Warszawie: 17 osób z dzielnicy Białołęka, 14 osób z dzielnicy Targówek, 12 osób z Pragi Południe. Warto pokreślić, że większość tych osób mieszkała wcześniej w lewobrzeżnej części Warszawy. Mieszkańcy osiedla Lykke to w przeważającej mierze osoby aktywne zawodowo (77,9\%). Ponad 65\% badanych posiada samochód, a 21,1\% mieszka z dziećmi. Ponad 70\% respondentów nie ma żadnego multikarnetu sportowego. Ponad połowa gospodarstw domowych na osiedlu Lykke jest dwuosobowych.

\section{Aktywność fizyczna mieszkańców osiedla Lykke}

Regularną aktywność fizyczną podejmuje ponad 70\% ankietowanych. Jednocześnie prawie $65 \%$ z nich uznaje się za osoby aktywne fizycznie. Jest to wysoki odsetek, gdyż jak wskazują badania przeprowadzone przez Główny Urząd Statystyczny, regularną aktywność fizyczną podejmuje jedynie 20,3\% Polaków. W miastach powyżej 500 tys. mieszkańców odsetek ten wynosi 52,3\%, a na obszarach wiejskich 40,5\%.

Mieszkańcy osiedla Lykke najczęściej podejmują aktywność fizyczną 2-3 razy w tygodniu (49\%), ale wśród ankietowanych są osoby robiące to częściej: 4-5 razy w tygodniu (27\%) i ponad 6 razy w tygodniu (ok. 10\%). Aktywność fizyczna podejmowana jest zarówno w dni powszednie, jak i w dni wolne od pracy. Najpopularniejszą aktywnością jest rower (47\%), po nim bieganie (39\%), na dalszym miejscu pływanie $(29,6 \%)$ oraz fitness $(23,2 \%)$. Wśród mieszkanek osiedla Lykke najpopularniejszy jest rower $(57,6 \%)$ oraz fitness i pływanie (po 39,4\%), bieganie to dyscyplina podejmowana 
przez 27,3\% pań. Wśród mężczyzn dominuje bieganie $(54,1 \%)$ oraz rower $(51,5 \%)$, na dalszym miejscu znajduje się piłka nożna (36,4\%).

Mieszkańcy wskazali również bariery, które ograniczają ich aktywność. Do barier takich zalicza się w przypadku kobiet: brak nawyków (43,9\%), brak motywacji (42,2\%) oraz brak czasu (36,5\%), a wśród mężczyzn: brak czasu (34,3\%), brak motywacji $(29,4 \%)$ oraz zdrowie (29,2\%). Wśród osób, dla których stan zdrowia jest barierą podejmowania aktywności fizycznej, były tylko dwie osoby w wieku powyżej 60. roku życia.

\section{Postrzeganie przestrzeni osiedla Lykke przez mieszkańców}

Najważniejszym powodem wyboru mieszkania na osiedlu Lykke była architektura osiedla i jego wygląd (ok. 80\% wskazań). Drugim powodem była cena mieszkania (60\%), a kolejnym tereny znajdujące się wokół osiedla (55\%). Można wnioskować, że koncepcja osiedla Lykke (architektura, wyposażenie) i jego usytuowanie w sąsiedztwie terenów zieleni i rekreacyjnych zostały dostrzeżone przez klientów i zaważyły na decyzji o zakupie mieszkania. Warto podkreślić, że cena mieszkania na osiedlu Lykke nie należała do najniższych w tej okolicy, co dodatkowo podkreśla istotność wyżej wskazanych czynników. Można uznać, że klient był świadomy prezentowanej oferty i był skłonny zdecydować się na mieszkanie droższe, ale na osiedlu o wyższym standardzie i lepszym wyposażeniu. Marginalne znaczenie dla wyboru mieszkania miały czynniki zewnętrzne: położenie w dzielnicy, położenie w Warszawie, sąsiedztwo centrów handlowych czy bliskość znajomych i miejsca pracy.

Osiedle Lykke zostało ocenione przez mieszkańców pod względem wielkości, liczby i wielkości bloków oraz liczby miejsc parkingowych. Zarówno wielkość osiedla, jak i liczba i wielkość bloków uznane zostały za odpowiednie przez ponad 90\% respondentów. Jedynie liczba miejsc parkingowych wydaje się niewystarczająca $(33,7 \%)$, za odpowiednią uznało ją mniej niż 50\% badanych. Do największych atutów osiedla mieszkańcy zaliczyli architekturę, jego kameralność i sposób zagospodarowania. Słabe strony osiedla to: niewystarczająca liczba ławek, brak garaży, parkingu dla rowerów oraz piwnic i huśtawek.

Dla ponad $80 \%$ respondentów oferta rekreacyjna osiedla Lykke jest przynajmniej dobra, a bardzo dobra dla 35,1\% mieszkańców (tabele 2 i 3). Ponad 60\% badanych korzysta z zagospodarowania osiedla i jednocześnie uznaje je za ciekawe. Pozytywną opinię o zagospodarowaniu osiedla ma również 20,8\% badanych, ale nie korzysta $\mathrm{z}$ tej oferty. Jedynie 8,3\% respondentów uznało rekreacyjną infrastrukturę osiedla za mało interesującą. Najwięcej pozytywnych ocen oferty rekreacyjnej prezentują osoby określające się jako aktywne fizycznie (łącznie 87,7\%). Osoby, które uznają się za umiarkowanie aktywne, częściej też neutralnie oceniają ofertę rekreacyjną osiedla. Co istotne, dla osób uznających się za nieaktywne fizycznie oferta rekreacyjna również jest bardzo dobra i dobra (80\%), ale jednocześnie w tej grupie nie ma osób oceniających tę ofertę negatywnie. 
Ocena oferty rekreacyjnej osiedla Lykke a ocena aktywności fizycznej respondenta

\begin{tabular}{|l|c|c|c|}
\hline \multicolumn{1}{|c|}{$\begin{array}{c}\text { Ocena oferty } \\
\text { rekreacyjnej osiedla }\end{array}$} & $\begin{array}{c}\text { Osoby aktywne } \\
\text { fizycznie }\end{array}$ & $\begin{array}{c}\text { Osoby ani aktywne, ani } \\
\text { nieaktywne fizycznie }\end{array}$ & $\begin{array}{c}\text { Osoby nieaktywne } \\
\text { fizycznie }\end{array}$ \\
\hline Bardzo dobra & $40,0 \%$ & $12,5 \%$ & $38,5 \%$ \\
Dobra & $47,7 \%$ & $56,3 \%$ & $38,5 \%$ \\
Neutralna & $12,3 \%$ & $25,0 \%$ & $23,1 \%$ \\
Zła & $0,0 \%$ & $6,3 \%$ & $0,0 \%$ \\
Bardzo zła & $0,0 \%$ & $0,0 \%$ & $0,0 \%$ \\
\hline
\end{tabular}

Źródło: Jak w tabeli 1.

Tabela 3

Opinia o ofercie rekreacyjnej osiedla a ocena aktywności fizycznej respondenta

\begin{tabular}{|l|c|c|c|}
\hline \multicolumn{1}{|c|}{$\begin{array}{c}\text { Opinia na temat } \\
\text { oferty rekreacyjnej osiedla }\end{array}$} & $\begin{array}{c}\text { Osoby aktywne } \\
\text { fizycznie }\end{array}$ & $\begin{array}{c}\text { Osoby ani aktyw- } \\
\text { ne, ani nieaktywne } \\
\text { fizycznie }\end{array}$ & $\begin{array}{c}\text { Osoby nieaktywne } \\
\text { fizycznie }\end{array}$ \\
\hline Oferta jest ciekawa, korzystam z niej & $70,8 \%$ & $31,3 \%$ & $53,3 \%$ \\
\hline $\begin{array}{l}\text { Oferta jest ciekawa, ale z niej nie } \\
\text { korzystam }\end{array}$ & $16,9 \%$ & $31,3 \%$ & $26,7 \%$ \\
\hline $\begin{array}{l}\text { Oferta jest ciekawa, ale niedostoso- } \\
\text { wana do moich potrzeb }\end{array}$ & $4,6 \%$ & $18,8 \%$ & $20,0 \%$ \\
\hline $\begin{array}{l}\text { Oferta jest mało interesująca, } \\
\text { a chciałbym z niej korzystać }\end{array}$ & $4,6 \%$ & $12,5 \%$ & $0,0 \%$ \\
\hline $\begin{array}{l}\text { Oferta jest mało interesująca, nasta- } \\
\text { wiona na wąską grupę odbiorców }\end{array}$ & $3,1 \%$ & $6,3 \%$ & $0,0 \%$ \\
\hline
\end{tabular}

Źródło: Jak w tabeli 1.

Pewna grupa mieszkańców już korzysta z urządzeń rekreacyjnych: 39,6\% z boisk, 43,6\% z siłowni plenerowej, 22,5\% ze stanowisk do szachów i 11,9\% z wybiegu dla psów (tabela 4). Wysoki jest również stopień deklaracji chęci korzystania z urządzeń w przyszłości. Taki zamiar wyraża 45,8\% mieszkańców w odniesieniu do boisk, 36,2\% w odniesieniu do siłowni i 44,1\% w odniesieniu do stanowiska do gry w szachy. Najmniejszym zainteresowaniem cieszy się wybieg dla psów - blisko $67 \%$ respondentów nie zamierza z niego korzystać. Warto zauważyć, że wśród osób korzystających z oferty rekreacyjnej osiedla są te, które oceniają się jako nieaktywne fizycznie i jednocześnie w tej grupie zaobserwowano wysoki stopień deklaracji chęci korzystania z tej oferty w przyszłości - w odniesieniu do boiska jest to aż 64,3\%. W odniesieniu do siłowni wysoki jest odsetek osób nieaktywnych fizycznie, a jednocześnie korzystających z tej części osiedla - sporadycznie z siłowni korzysta $14,3 \%$, a czasami $28,6 \%$ osób oceniających się jako nieaktywne. Można z pewną ostrożnością uznać, że wyposażenie osiedla wpływa 
(lub wpłynie) na podniesienie poziomu aktywności mieszkańców, a osoby do tej pory mało aktywne lub nieaktywne nakłoni do zmiany swych przyzwyczajeń.

Korzystanie z poszczególnych elementów zagospodarowania osiedla a ocena aktywności fizycznej respondenta

\begin{tabular}{|l|r|r|r|r|r|r|}
\hline \multirow{2}{*}{ Wyszczególnienie } & \multicolumn{3}{|c|}{ Boisko } & \multicolumn{3}{c|}{ Siłownia } \\
\cline { 2 - 7 } & \multicolumn{1}{|c|}{1} & \multicolumn{1}{|c|}{2} & \multicolumn{1}{c|}{3} & 1 & \multicolumn{1}{c|}{2} & \multicolumn{1}{c|}{3} \\
\hline Regularnie & $13,6 \%$ & $6,3 \%$ & $7,1 \%$ & $10,9 \%$ & $0,0 \%$ & $7,1 \%$ \\
Czasami & $24,2 \%$ & $18,8 \%$ & $0,0 \%$ & $23,4 \%$ & $6,3 \%$ & $28,6 \%$ \\
Sporadycznie & $9,1 \%$ & $6,3 \%$ & $7,1 \%$ & $12,5 \%$ & $18,8 \%$ & $14,3 \%$ \\
Nie, ale zamierza & $40,9 \%$ & $50,0 \%$ & $64,3 \%$ & $37,5 \%$ & $37,5 \%$ & $28,6 \%$ \\
Nie, ale korzystał & $0,0 \%$ & $0,0 \%$ & $0,0 \%$ & $3,1 \%$ & $6,3 \%$ & $0,0 \%$ \\
Nie i nie zamierza & $10,6 \%$ & $18,8 \%$ & $21,4 \%$ & $10,9 \%$ & $31,3 \%$ & $21,4 \%$ \\
Nie wie, że są & $1,5 \%$ & $0,0 \%$ & $0,0 \%$ & $1,6 \%$ & $0,0 \%$ & $0,0 \%$ \\
\hline
\end{tabular}

1 - osoby aktywne fizycznie, 2 - osoby ani aktywne, ani nieaktywne fizycznie, 3 - osoby nieaktywne fizycznie (wg opinii respondentów)

Źródło: Jak w tabeli 1.

Dużym atutem osiedla jest jego położenie i sąsiedztwo terenów zieleni i innych terenów rekreacyjnych. Ponad $90 \%$ respondentów korzysta z wymienionych przestrzeni, $\mathrm{w}$ tym ponad $50 \%$ robi to regularnie. Rzadziej respondenci korzystają z boisk (36,9\%), siłowni plenerowych $(34,4 \%)$ oraz klubów fitness $(29,8 \%)$, jednocześnie deklarują chęć korzystania z tych obiektów w przyszłości (27,4\% w przypadku boisk, 27,7\% w przypadku klubów fitness i 18,3\% w przypadku siłowni plenerowych).

Pomimo krótkiego czasu zamieszkania na osiedlu mieszkańcy wykształcili już pewne relacje sąsiedzkie i można je uznać za dość silne. Większość (70\%) respondentów rozpoznaje innych mieszkańców osiedla, podejmuje z nimi rozmowy (blisko 60\%), pomaga sobie wzajemnie (ponad 35\%), odwiedza się w domach (32\%) i spędza wspólnie czas na terenie osiedla (blisko 25\%). Relacje sąsiedzkie zostały nawiązane w dużej części jeszcze przed wprowadzeniem na osiedle. Posłużyły temu przede wszystkim przeprowadzka $(51,7 \%)$ oraz forum internetowe $(41,6 \%)$. Po zamieszkaniu relacje sąsiedzkie formują się na klatkach schodowych $(55,1 \%)$, w przestrzeni osiedla $(46,1 \%)$ oraz na parkingu (27\%).

Według respondentów Lykke najlepiej nadaje się do zamieszkania przez małżeństwa z dziećmi (91,5\%). Najmniej wskazano skojarzeń z osobami starszymi (48,3\%). Jednocześnie w opinii mieszkańców osiedle zamieszkane jest przede wszystkim przez małżeństwa z dziećmi (38\%) oraz osoby młode (29\%). Warto też zauważyć, że jedynie $21,1 \%$ respondentów mieszka z dziećmi, co może się wiązać z planami powiększenia rodziny przez osoby zamieszkujące to osiedle. 


\section{Podsumowanie}

Podejście do kształtowania przestrzeni osiedlowej zastosowane na osiedlu Lykke należy uznać za bardzo interesujące. Obejmuje ona obiekty związane (poza budynkami mieszkaniowymi i parkingiem) z aktywnością fizyczną i rekreacją. Sprzyja temu również sąsiedztwo osiedla obfitujące w tereny zieleni, bliskość Zalewu Zegrzyńskiego, stadninę koni, kluby fitness i inne urządzenia rekreacyjne. Koncepcja osiedla - architektura, sposób zagospodarowania oraz jego usytuowanie w sąsiedztwie terenów zieleni i rekreacyjnych -została dostrzeżona przez klientów i zaważyła na decyzji o zakupie mieszkania. Sam sposób zagospodarowania osiedla stanowił o jego wysokiej atrakcyjności, co może się stać pewnym drogowskazem dla nowo planowanych kompleksów mieszkaniowych, które również w swoich projektach powinny uwzględniać potrzeby związane z aktywnością fizyczną. Sukces twórców osiedla w odniesieniu do jego zagospodarowania potwierdziły przeprowadzone badania - ponad 60\% mieszkańców korzysta z oferty rekreacyjnej osiedla, a na samym osiedlu zamieszkały osoby o wysokim stopniu aktywności fizycznej.

Osiedle Lykke może się stać początkiem nowego podejścia w kształtowaniu przestrzeni mieszkaniowej, w której nacisk zostanie położony na aktywność fizyczną i rekreację mieszkańców. Z jednej strony można to uznać za ciekawe podejście marketingowe inwestora i sposób na pozyskanie nowych klientów, ale z drugiej strony wybór funkcji, wokół której koncentruje się całe zagospodarowanie, należy uznać za nowatorski. Potrzeba ruchu i aktywności z wielu powodów była i będzie ważną pozycją w hierarchii potrzeb człowieka, a biorąc pod uwagę negatywne zjawiska w zakresie zdrowia, jej rola w podnoszeniu jakości życia będzie jeszcze większa. Prezentowana koncepcja kształtowania przestrzeni osiedla może się stać jednym ze sposobów radzenia sobie z brakiem aktywności mieszkańców (dyfuzja wzorców, tworzenie nawyków i budowanie motywacji) lub utrzymywania i wspierania obecnej, ukształtowanej aktywności (kontynuacja zachowań rekreacyjnych).

\section{Bibliografia}

Brukalska B., 1948, Zasady społeczne projektowania osiedli mieszkaniowych, Instytut Gospodarstwa Społecznego, Warszawa.

Chmielewski J.M., Mirecka M., 2001, Modernizacja osiedli mieszkaniowych, Oficyna Wydawnicza Politechniki Warszawskiej, Warszawa.

http://www.mck.pk.edu.pl/panel/dokumenty/PPS,\%20Jak_przetworzyc_miejsce.pdf (dostęp 25 marca 2017). Jak przetworzyć miejsce. Podręcznik kreowania udanych przestrzeni publicznych, Project for Public Spaces, Inc., NFOiGW,

Komar B., 2012, Analiza historyczna rozwoju osiedli mieszkaniowych: Gruenau w Lipsku i im. Tysiąclecia w Katowicach na tle wzorcowych koncepcji mieszkalnictwa XX wieku, „Architecturae et Artibus” 2012, 2.

Korzeniewski W., 1989, Budownictwo mieszkaniowe. Poradnik projektanta, Arkady, Warszawa. Lipińska A., 1977, Rola zieleni w osiedlu mieszkaniowym, Państwowe Wydawnictwo Naukowe, Warszawa. 
Nowa Karta Ateńska 2003. Wizja miast XXI wieku, Lizbona 20 listopada 2003 r., http://www.zabytki-tonz. pl/pliki/karta\%20atenska\%202003_pl.pdf (dostęp 25 marca 2017).

Ostrowski W., 1971, Osiedle mieszkaniowe - materiaty pomocnicze do projektu urbanistycznego, Wydawnictwa Politechniki Warszawskiej, Warszawa.

Piątkowska K., Scholtz A., Wirszyłło R., 1976, Rekreacja w osiedlu, Zakład Wydawnictw CRS, Warszawa.

Syrkus H., 1976, Ku idei osiedla społecznego 1925-1975, Państwowe Wydawnictwo Naukowe, Warszawa.

Szkiłądź J., 1979, Elementy zagospodarowania terenów osiedlowych, Zakład Wydawnictw Centralnego Związku Spółdzielni Rolniczych, Warszawa. 